\title{
Sejarah Kurikulum Pendidikan Islam di Brunei Darussalam
}

Aslan $^{1}$, Suhari $^{2}$

1,2, Institut Agama Islam Sultan Muhammad Syafiuddin Sambas, Indonesia

Corresponding Author: Aslan, E-mail: aslanmarani88@yahoo.com

\section{ABSTRACT}

This artilce aimed to analyze of hisotorical Islamic education curriculum in Brunei. This method used field of study or literature.

ARTICLE INFO

Article history:

Received

8 April 2019

Revised

25 May 2019

Accepted

1 June 2019
The result showed that Firstly, after Islam came to Brunei, the education system was more in the direction of printing scholars. Secondly, after the arrival of invaders in Brunei, Islamic religious education has experienced dualism, but the curriculum from the Britain has not received a warm welcome. Thirdly, Brunei's independence was inseparable from the role of Britain, so education in Brunei was inseparable from the influence of the educational curriculum of the British nation.

Keywords: Islaimic Education Curriculum, Historical Education of Brunnei Darussalam

DOI

Journal Homepage $\quad:$ http://journal.iaimnumetrolampung.ac.id/index.php/ji/

This is an open access article under the CC BY SA license

: https://creativecommons.org/licenses/by-sa/4.0/

\section{PENDAHULUAN}

Kurikulum pendidikan dalam sebuah negara dianggap penting, karena kurikulum merupakan salah satu visi dan misi negara untuk memajukan negaranya, karena tanpa kurikulum maka negara seperti halnya tidak memiliki kompas sebagai penunjuk arah tujuan yang diinginkan. Namun, dalam kenyataannya bahwa setiap kurikulum yang dijadikan acuan dalam sebuah pendidikan tidak terlepas dari sejarah yang menaunginya di setiap negara, seperti halnya dengan negara Brunei Darussalam.

Brunei berasal dari bahasa sansekerta "Varunai", diambil dari kata "Varunadvipa" yang artinya Pulau Kalimantan, sekaligus daerah Brunei berada dikawasan Pulau Kalimantan. Brunei terletak di Barat Daya Pulau Borneo atau Sabah. Pada awalnya Brunei adalah wilayah yang amat besar, tetapi sejak adanya kedatangan penjajah sehingga Brunei menjadi negara yang begitu kecil. Brunei berhadapan dengan Laut Cina Selatan yang berada di Serawak, Malaysia distrik yaitu "Tutung, Belait, Temburong, dan distrik Brunei atau Muara". Jumlah jiwa yang ada di Brunei sekitar 66.000 jiwa dan 59\% adalah 
penduduk campuran. Suku yang paling terbesar di Brunei adalah Melayu muslim sejumlah 90\%, 1/5 etnis Cina dan sisanya adalah etnis India. Bahasa yang utama digunakan di Brunei adalah bahasa Melayu, sementara bahasa lainnya seperti Inggris, Cina Iban yang secara keseluruhan Brunei mempunyai 17 bahasa. Brunei juga dikenal sebagai negara yang kaya raya di salah satu negara Asia Tenggara, yang kekayaan yang paling terbesar adalah minyak bumi (Ghofur, 2015 ; Cahyani, 2015). Dilihat dari jumlah etnis yang ada di Brunei terdapat etnis yang paling terbesar adalah Suku Melayu yang mayoritas beragama Islam. Oleh karena itu, agama Islam yang dimiliki oleh negara Brunei tidak terlepas sejarah agama Islam yang masuk di negara Brunei tersebut.

Berdasarkan "catatan Fa-Hsien tahun 413-144 M", Brunei dikenal dengan sebutan Ye-po-ti, yang mana sebutan itu tidak secara langsung disebutkan kepada negara Brunei tetapi lebih ditujukan kepada negara Borneo. Brunei pada waktu itu dijadikan sebagai tempat persinggahan pelayaran dari berbagai macam agama, seperti India ke Cina ataupun sebaliknya, sehingga membawa pengaruh bagi agama Islam di Brunei (Utomo, 2011 ; Putra \& Pasa, 2016). Hal yang begitu jelas, masuknya agama Islam di Brunei terdapat adanya Batu nisan yang bertuliskan arab, dengan tulisan "batu nisan al-Mukhdarah" pada tahun 440 H/1028 M (Musa, 2005). Adanya batu nisan yang bertulisan arab tersebut, memberikan gambaran yang begitu jelas terhadap masuknya agama Islam di Brunei, karena mana mungkin agama yang lain bisa menulis arab. Apalagi, bahasa pada waktu itu tidak terlalu dikenal oleh masyarakat luas di seluruh dunia, seperti halnya pada zaman sekarang.

Kemudian, masuknya agama Islam di Brunei, terdapat adanya catatan sejarah Cina pada tahun 1370 M, yang rajanya bernama Ma-ha-mo-sya atau dikenal sebagai Sultan Mohammad Syah. Ia telah membawa sepucuk surat yang menggunakan tulisan khat yang persis dari tulisan agama Islam dari keturunan Turki di daerah Uigur, sehingga dapat juga dipastikan bahwa agama Islam telah masuk ke Brunei sebelum tahun 1368 M. Selanjutnya, berdasarkan riwayat Cina lainnya, bahwa utusan Cina yang diketuai oleh seorang Islam yang bernama Cheng Ho, pernah datang ke Brunei pada tahun 1405. Pada saat Cheng Ho datang ke Brunei, maka Brunei terlebih dahulu telah ada kerajaan Islam dan keluarga raja dengan gelar Pangeran (Putra Daulay \& Pasa, 2016). Agama Islam yang berperan penting sejak masuknya agama Islam di negara Brunei, maka memberikan sejarah yang penting juga bagi lembaga pendidikan Islam di Brunei pada waktu itu, tetapi pendidikan Islam tersebut tidaklah lama bertahan, karena Brunei juga telah kedatangan kaum penjajah seperti halnya dengan negara-negara Asia Tenggara lainnya, sehingga tidak dipungkiri juga 
tentang corak yang beragam dari sejarah perjalanan pendidikan agama Islam di Brunei.

Kajian mengenai kurikulum pendidikan ditinjau dari history sudah banyak di kaji oleh para penelitian terdahulu. Seperti yang telah dilakukan oleh Aslan (2019) yang memaparkan bahwa sejak kaum penjajah datang ke Malaysia, maka Malaysia menganut sistem kerajaan, sehingga sistem pendidikannya pun sesuai keinginan raja. Raja Malaysia yang menganut agama Islam, maka orientasi pendidikannya tidak terlepas ke Islam. Setelah penjajah datang ke Malaysia, Portugis, Belanda, Inggris dan Jepang maka sistem pendidikan sudah mengalami dualisme antara keinginan raja Malaysia dan kaum penjajah. Kedatangan penjajah yang paling semena-mena di Malaysia adalah Jepang, sehingga untuk mengusir Jepang maka meminta bantuan kepada Inggris. Dari bantuan kemerdekaan Inggris tersebut maka sistem pendidikan di Malaysia lebih orientasinya ke Inggris, yakni harus bisa berbahasa Inggris, walaupun bahasa Melayu sebagai bahasa resmi di Malaysia. Yang kedua Fitrianah (2018) yang telah melakukan penelitian di Asia Tenggara di Malaysia, Filipina, Singapura dan Brunei Darussalam. Dari penelitian yang telah dilakukan tentang Negara Brunei hanya sepintas tanpa memberikan sejarah awal negara Brunei terbentuk. Hal ini memberikan gambaran bahwa sejak Brunei dijajah dan kemerdekaannya diberikan oleh Inggris pada tahun 1 Januari 1984, maka sistem pendidikan yang digunakan terdiri dari dwi bahasa, yakni bahasa Melayu dan Inggris yang wajib untuk dikuasi oleh orang Brunei. Selanjutnya Najtama (2018) yang telah melakukan penelitian tentang perkembangan Islam di Brunei. Hasil penelitian yang dilakukan tentang Brunei lebih menitik beratkan kepada sejarah Brunei tetapi dari segi pendidikan hanya dibahas secara singkat, yang hanya tergambar ketika Inggris datang tanpa diberi gambaran sama sekali ketika Islam masuk di Brunei.

Perbedaan peneliti yang telah dilakukan dengan penelitian terdahulu adalah bahwa penelitian ini menceritakan tentang sejarah kerajaan Brunei, baik ketika Islam belum datang maupun sesudahnya. Perkembangan Islam semakin meluas ketika Brunei dipimpin oleh seorang raja sekaligus raja pertama Brunei adalah Islam. Ketika Islam masuk, maka sistem pendidikan lebih berkibatkan kepada raja yang berorientasi pendidikan agama Islam. Ketika penjajah datang maka sistem pendidikan Brunei mengalami dualisme perubahan antara Inggris dan Brunei, tetapi eksistensi keislaman di Brunei sama sekali tidak hilang, sehingga walaupun penjajah datang ke Brunei tidak merubah sama sekali keyakinan agama dan sistem pendidikan agama Islamnya. 
Kajian tentang kurikulum pendidikan islam di Brunei Darussalam sangat penting untuk dihadirkan sebagai upaya lebih lanjut tentang kurikulum pendidikan Islam di Brunei Darussalam yang mencakup beberapa pembahasan, yakni sejarah kerajaan Brunei Darussalam dan sejarah pendidikan Islam di Brunei Darussalam. Tujuan dari penelitian ini, penulis tidak menceritakan lebih luas tentang kurikulum, karena secara garis besar pengertian kurikulum sama halnya dengan penelitian-penelitian lainnya, tetapi lebih memfokuskan pada histroy kurikulum pendidikan islam di Brunei Darussalam yang membahas perjalanan sejarah pendidikan di Brunei Darussalam.

\section{METODE PENELITIAN}

Metode yang digunakan dalam penelitian ini adalah metode kualitatif dengan kajian dokumen. Dalam istilah Creswell (1994) penelitian ini disebut sebagai penelitian study literature, dengan cara menelaah jurnal, buku, laporan penelitan, majalah dan literatur lainnya yang sesuai dengan pembahasan yang dikaji dalam penelitian ini. Dalam pengumpulan data kajian study literature, penulis melakukan; Pertama, melalui kajian kepustakaan yang sesuai dengan bahan yang diteliti. Kedua, setelah data diperoleh, maka penulis menganalisis data-data tersebut sesuai dengan pemahaman penulis dalam melakukan kajian ini.

\section{HASIL PENELITIAN DAN PEMBAHASAN}

Beberapa kajian penelitian yang dilakukan oleh Aslan (2018) yang lebih banyak bercerita tentang sejarah perjalanan kurikulum di Malaysia, kemudian Rossi Delta Fitrianah (2018), yang hanya secara singkat membahas pendidikan Islam di Negara Brunei Darussalam yang lebih membicarakan tetang pendidikan pendidikan ketika Brunei Darussalam dijajah oleh Inggris dan Fikria Natjama (2018) hanya menceritakan sejarah Brunei tanpa membahas sedikitpun tentang pendidikannya. Oleh karena itu, hasil penelitian yang dilakukan oleh peneliti dengan menggunakan metode kualitatif dengan kajian dokumen, dengan mencakup dua pembahasan, yakni; Pertama, Sejarah Kerajaan Brunei Darussalam. Kedua, sejarah pendidikan Islam di Brunei Darussalam. 


\section{Sejarah Kerajaan Brunei Darussalam}

Kerajaan Brunei dilihat dari sejarahnya tidak terdapat bukti yang begitu otentik tentang kehadirannya, tetapi jika ditelusuri lebih jauh dari kajian-kajian sejarah, maka adanya kehadiran negara Brunei terlihat dengan jelas dari sistem pemerintahannya dari dahulu dan berimbas di masa sekarang, yang berawal dari; Pertama, pada masa era Pra-Kesultanan dari negara Brunei yang terlihat dari kerajaan Vijayapura dan kerajaan Po-ni. Hadirnya kerajaan Vijayapura berdasarkan dari sumber kerajaan Cina dan Nusantara yang mengelola negara Brunei. Namun, kerajaan ini tidak bertahan begitu lama, karena telah ditaklukkan oleh Sriwijaya, sementara kerajaan Po-ni menguasai Brunei pada abad ke-10. Kedua, era kesultanan. Menjelang kehancuran Dinasti Yuan, Cina mengalami kekacauan yang begitu parah sehingga mengakibatkan Cina lari dari Brunei. Mereka melarikan diri ke arah Timur Kalimantan dan masuk ke daerah sungai, tetapi sungai tersebut membawa mala petaka dari salah satu Suku Cina, yakni kehilangan anggota lengannya, sehingga sungai tersebut diberi nama dengan "Kinabatangan" yang artinya hilangnya lengan tangan seseorang. Namun, inisiatif meninggalkan daerah Brunei, ternyata membawa dampak positif bagi Cina, karena tempat yang dijadikan pelarian tersebut dapat memakmurkan bagi Suku Cina yang melakukan pelarian sehingga inisiatif dari salah satu Suku Cina tersebut dijadikan sebagai pemimpin atau dalam istilah sosial disebut sebagai agent of change. Pemimpin tersebut bernama Ong Sum Ping. Bagi orang Melayu Ong Sum Ping dikenal dengan Chung Ping yang artinya Jenderal. Ketiga, era penjajahan Inggris. Brunei mengalami kekalahan terhadap Spanyol sehingga membawa petaka bagi negaranya. Atas kejadian ini, wilayah yang begitu besar di Brunei sehingga rakyat yang tinggal diberbagai daerah masing-masing menuntut kemerdekaannya tetapi masih bisa diredam, tetapi hanya beberapa abad saja. Kemudian tiga abad kemudian, Brunei mengalami perpecahan dan pemberontakan di Sarawak pada masa Sultan Omar Ali Saifuddin II pada tahun 1839, tetapi kesultanan Brunei mendapatkan bantuan dari James Brooke, sehingga konflik tersebut bisa dipadamkan. Atas bantuan Brooke bagi negara Brunei sehingga ia diangkat menjadi gubernur Sarawak dan diberi gelar sebagai Raja Putih. Akan tetapi, bantuan tersebut, Brooke mempunyai niat yang lain, yang mana Brooke ingin menguasai negara Brunei seluruhnya tetapi tujuan tersebut terlebih dahulu diketahui oleh Kesultanan Brunei pada tahun 1843, sehingga keinginan tersebut tidak berhasil sebagaimana yang direncanakan sebelumnya. Akhirnya, niat yang tidak baik tersebut menyebabkan kesultanan Brunei dan Brooke konflik secara terbuka tetapi konflik tersebut dimenangkan Brooke dan akhirnya Sarawak berdiri sendiri. Namun, disisi lain, membuat Inggris lebih mudah 
untuk menguasai Sarawak, yang mana Inggris melakukan serangan kepada Brunei dan akhirnya dimenangkan oleh Inggris dan akhirnya Brunei dikuasai oleh Inggris. Sultan Saifuddin II dipaksa oleh Inggris untuk menandatangani perjanjian Labuan yang isinya "perdagangan dan persahabatan dengan Inggris" dan pada tahun 1850 melakukan perjanjian kepada Amerika Serikat sehingga mengakibatkan wilayah Brunei semakin mengecil (Chomsky, 2014) Kekalahan demi kekalahan dalam konflik tersebut, yang pada awalnya Brunei adalah sebuah negara yang begitu besar, tetapi karena adanya niat politik yang negatif, mengakibatkan wilayah Brunei yang begitu besar menjadi semakin mengecil. Brooke yang pada awalnya dianggap sebagai pahlawan tanpa jasa untuk membantu di wilayah sebagian Brunei yakni Sarawak menjadi pahlawan yang berambisi besar untuk menguasai Brunei seluruhnya. Namun, niat tersebut tidak tercapai sebagaimana apa yang diinginkan, tetapi setidaknya kekuasaan Brooke di Sarawak pada waktu itu bisa mengalahkan kesultanan Brunei. Hal yang begitu menarik dari Brooke adalah tujuan untuk membantu Brunei maka terlebih dahulu disiapkan segala-galanya dari segi politik sehingga bisa mengalahkan kesultanan Brunei yang mempunyai kekuasaan yang begitu besar di Brunei, tetapi tidak mempunyai kesiapan dari segi politik sehingga untuk mengambil alih negara Sarawak tidak bisa dimenangkan. Kekuasaan Kesultanan Brunei tahun demi tahun bukan saja mengalami kemundurun tetapi ikut juga mengalami kekuasaan lainnya sejak kedatangan kaum penjajah Inggris untuk menguasai Brunei.

Pada tahun 1856, Kesultanan Brunei telah memberikan kuasa penuh kepada Inggris untuk mengendalikan kasus yang timbul dari pertikaian antara rakyat Inggris dengan rakyat asing di negara Kesultanan Brunei. Kemudian pada tahun 1888, Kesultanan Brunei memberikan kuasa yang semakin penuh terhadap kuasa hukum Inggris (Cahyani, 2015). Brunei yang tidak mampu untuk mengendalikan kasus yang ada di Negaranya sehingga memberikan kekuasaan penuh terhadap Inggris karena Inggris dianggap mampu untuk menyelesaikan konflik yang terjadi dan meredam konflik tersebut.

Pada tahun 1888 juga, bukan hanya negara Brunei yang dikuasai oleh Inggris, tetapi negara Malaysia ikut juga dikuasai. Oleh karena itu, untuk mengusir bangsa penjajah dari Inggris ini, maka kedua negara ini bersatu untuk merebut kembali negaranya dari bangsa penjajah. Namun, kemerdekaan memang bisa direbut tetapi tidak terlepas juga dari bangsa Inggris yang memberikan kemerdekaan tersebut. Pertikaian demi pertikaian terus berlanjut yang bukan hanya dengan bangsa Inggris tetapi terjadi juga dengan bangsa Cina dan Melayu dari masyarakat pribumi Brunei pada tahun 1960. Masing- 
masing kedua negara mengamankan negaranya, kemudian setelah aman baru Brunei memisahkan diri dari negara Malaysia (Bani, 2008).

Dari beberapa pengertian tentang terbentuknya sejarah kerajaan negara Brunei sejak kedatangan agama Islam dan bangsa penjajah tetapi disisi yang begitu menarik kerajaan Brunei ini adalah tidak terlepas dari peran Kesultanan sehingga sampai saat ini Brunei dianggap sebagai negara yang memiliki corak pemerintahan monarki absolut berdasarkan hukum Islam yang mana Sultan menjabat sebagai Kepala Negara dan Kepala Pemerintahan, sekaligus merangkap sebagai Perdana Menteri dan Menteri Pertahanan dan juga dibantu oleh Dewan Penasehat Kesultanan dan beberapa Menteri. Kesultanan Brunei telah berdiri sejak abad ke 15 M (Ghofur, 2015). Hukum-hukum Islam masih tetap berjalan sebagaimana mestinya, walaupun adanya kehadiran Suku yang lain di Brunei, tetapi hukum Islam menjadi hukum yang nomor satu di Brunei.

\section{Sejarah Pendidikan Islam di Brunei Darussalam}

Sebuah negara dilihat dari sisi sejarahnya, maka tidak terlepas dari kedatangan agama di negara tersebut, seperti halnya dengan negara Brunei Darussalam. Sebelum kedatangan agama Islam, dalam sejarahnya manusia dalam beragama tidak terlepas dari agama animisme dan dinamisme, tetapi sejak adanya kedatangan agama Islam, maka agama tersebut mengalami perpaduan antara Islam dan agama lama atau disebut agama sinkretik. Disatu sisi masyarakat sudah beralih kepada ajaran agama Islam tetapi disisi lain, masih tetap menjalankan agama ajaran nenek moyang tersebut. Diantara perpaduan ajaran agama ini memberikan warna bagi pendidikan di setiap negara termasuk negara Brunei Darussalam.

Sejak agama Islam datang ke Brunei, apalagi peran dari Kesultanan raja Brunei yang beragama Islam sehingga pendidikan agama Islam sangat menonjol dari negara ini. Pendidikan agama Islam pertama kali dilakukan seperti di rumah, masjid, surau, istana kerajaan dan tempat-tempat lainnya yang masih dianggap tradisional. Tenaga pengajarnya terdiri dari mubaligh, pedagang Islam, Imam, pembesar-pembesar negara dan orang alim di daerah yang bersangkutan. Sekitar abad ke 17-20 M, ulama Brunei dikenal dengan Catip atau khatib yang pengajiannya dilakukan di balai. Tujuan dari Balai ini adalah untuk menggantikan ulama-ulama nantinya sehingga sistem pengajiannya mempunyai dua kategori; Pertama, pengajian umum yang tidak mementingkan masalah menulis dan membaca jawi tetapi pengajiannya hanya berbentuk dzikir Brunei, Ratib Saman, mengaji al-Qur' an dan hadrah sekaligus belajar mengena ibadah sembahyang dan perkara lainnya. Kedua, pengajian yang menerapkan kepandaian dalam membaca dan menulis huruf jawi yang 
terdiri dari ilmu Fiqh, Faraidh, Babun Nikah, Nahu dan Qawaid, Tasawuf dan Akhlak. Sistem kurikulum pendidikan Islam tidak tidak bertahan dengan lama ketika Inggris datang ke Brunei. Pendidikan ala barat dari kedatangan Inggris di Brunei tersebut sudah mulai dilaksanakan pada tahun 1911. Pada awalnya, tulisan yang diperkenalkan oleh tokoh pendidik Islam di Brunei adalah huruf jawi, tetapi kedatangan Inggris tulisan tersebut digantikan dengan huruf rumi, sehingga kehadiran tulisan ini dari pendidikan yang diberikan oleh Inggris membuat bangsa Brunei tidak bisa menulis dan membaca dari huruf rumi ini (Nurudin, 2012).

Sejak kehadiran bangsa Inggris di Brunei yang bukan hanya mengambil kekayaan di Brunei tetapi membawa pengaruh bagi pendidikan agama Islam di Brunei. Pepaduan antara pola pendidikan Inggris dengan Brunei membawa dualisme pendidikan, yang mana pendidikan antara Brunei dengan Inggris, masih tetap saja berjalan. Akan tetapi, agama Islam yang menjadi agama bagi mayoritas terbesar Suku Melayu sehingga peran agama Islam tidak dengan mudah terpengaruh dari bangsa Inggris sejak kedatangan Inggris maupun setelah Brunei mendapatkan kemerdekaannya.

Apalagi, Inggris memberikan kekuasaan yang penuh dalam hal pendidikan yang terlihat dari kepedulian Inggris untuk meningkatkan pendidikannya yang nantinya akan dibiayai oleh Inggris jika pendidikan tersebut berhasil, karena pada sebelumnya dari tahun 1906-1924 dibawah kerajaan Sultan Muhammad Jamalul Alam tidak dapat meningkatkan pendidikan secara besar-besaran di Brunei. Bahkan pada saat pemerintahan Sultan Ahmad Tajuddin (1924-1950) kurang juga berhasil dalam hal pendidikan, karena sikap kehati-hatian pihak British terhadap kemauan kerajaan Brunei. British lebih memperhatikan kekayaan alam minyak bumi di Brunei dibandingkan pendidikannya (Suryani, 2014).

Negara Brunei Darussalam yang telah memperoleh kemerdekaan dari Inggris, maka pendidikan masih mengalami dualisme tetapi hukum Islam masih tetap saja berjalan sebagaimana mestinya. Dalam hal agama Islam, Brunei mengamalkan falsafah Melayu Islam Beraja (MIB) dengan menekankan pendidikan ajaran-ajaran Islam yang tujuan dari pendidikan tersebut adalah untuk melahirkan anak didik yang seimbang dari intelektual, rohani, emosi dan jasmani.(Lubis \& Aspar, 2005, hlm. 142) Filsafah ini secara resmi telah diberlakukan sejak pada tanggal 27 Rabiulawal 1404 Hijriah yang bertepatan dengan tanggal 1 Januari 1984 M. Isi dari kandungan falsafah Melayu Islam Beraja adalah “... Negara Brunei Darussalam adalah dan dengan izin serta limpah kurnia Allah Subhanahu wa Ta'ala akan untuk selama-lamanya kekal menjadi sebuah Negara Melayu Islam Beraja yang merdeka, berdaulat dan 
demokratik, bersendikan kepada ajaran-ajaran agama Islam menurut Ahli Sunnah wal Jama'ah....".(Klasik, t.t., hlm. 1) Ketetapan ini telah diberlakukan sejak raja ke 24, Sultan Abdul Momin (1852-1885). Apalagi, kekuasaan yang penuh dimiliki oleh raja, sehingga masyarkakat Brunei sangat hati-hati terhadap pengaruh dari luar. Bahkan, pada tahun 1991 disaat perayaan Isra' Mi'raj, Sultan telah mengeluarkan dekrit yang isinya melarang pergerakan AlArqam yang larangan itu sangat dihormati oleh masyarakat Brunei (Bani, 2008). Selain itu juga, raja Brunei melarang menjual minuman keras, berkhalwat (hubungan intim yang tidak sampai melakukan perbuatan zina), melakukan razia makanan yang tidak halal disetiap restoran dan juga memberikan batasan terhadap agama lain, seperti kristen, Budha, Hindu untuk menyebarkan agamanya secara bebas (Natalia, 2015). Ajaran agama Islam di Brunei semakin menyebar di berbagai daerah wilayah Brunei, tetapi ajaran agama selain Islam tidak diberikan pergerakan yang seluas-luasnya atas perintah kesultanan Brunei. Masyarakat Brunei juga taat terhadap ajaran agama Islam yang terlihat dari ketaatannya terhadap pemimpinnya.

Falsafah dari Melayu Islam Beraja (MIB) di Brunei lebih cenderung menganut Mazhab Syafi'i dan Mazhab Ahl Sunnah wal Jamaah, walaupun raja Brunei membebaskan rakyatnya untuk menganut mazhab lain selain syafi'i. Mazhab ini dilatarbelakangi sekitar abad ke 17 sampai $20 \mathrm{M}$, dengan standar kurikulum sistem kesultanan menggunakan kajian kitab Sabilah Muhtadin (karya Daud Fatani), al-Mukhtasar dan Siratal Mustaqim karya ar-Raniry, Ghayatut Taqrib fil Irthi wat-Tas'shib dan lain-lain. Selain itu juga, kepedulian raja Brunei terhadap rakyatnya terhadap agama Islam, terlihat dari keinginan raja agar semua rakyatnya bisa membaca al-Qur'an. Atas kebijakan ini sehingga raja Brunei menghabiskan uang yang begitu banyak untuk menerbitkan alQur'an dengan tulisan tangan yang ditulis oleh orang-orang khusus yang lebih memahami al-Qur'an. Bahkan, perusahaan yang besar di Mesir telah menerbitkan 150.000 exslamper ke sekolah-sekolah yang ada di Brunei. Raja Brunei juga menekankan pengajaran bahasa Melayu dengan huruf Jawi dan aksara rumi, sebagai tujuan untuk semakin memperkuat hubungan antara negara Melayu dengan warisan budaya Islam (Bani, 2008). Dilihat dari sistem pengajaran negara Brunei dari segi bahasa, maka Brunei juga sudah menggunakan sistem pendidikan ala barat yang berarti Brunei disatu sisi mengajarkan pendidikan Islam, tetapi disisi lain mengajarkan sistem pendidikan ala barat dan sekolah-sekolah yang didirikan oleh Inggris masih tetap saja berjalan walaupun Brunei telah memperoleh kemerdekaan.

Pada tahun 1913-1941, sekolah yang ada di Brunei berjumlah 32 buah sekolah, yang terdiri dari 24 sekolah Melayu, 3 sekolah swasta Inggris dan 5 
sekolah Cina. Sistem pendidikan khusus untuk siswa laki-laki juga didirikan pada tahun 1918, dengan usia 7-14. Kehadiran sekolah ala barat di Brunei kurang mendapat sambutan hangat dari rakyat Brunei. Oleh karena itu, agar rakyat Brunei merasa perlu untuk menyekolahkan anaknya sehingga raja Brunei mengadakan sosialisasi dan mengadakan sistem pembelajaran di mesjid dengan tujuan memberikan pehamaman kepada masyarakat awam Brunei bahwa sekolah ala barat tidak bertentangan dengan agama. Namun, strategi tersebut tidak juga berhasil, sehingga raja Brunei membuat peraturan yang disebut dengan “The School Attendance Enactment 1929 yang mewajibkan” orang tua untuk menyekolahkan anaknya ketika sudah memasuki umur 7-14 tahun dan denda antara 50 sen sampai seratus dolar. Strategi ini juga tidak secara menyeluruh berhasil di wilayah-wilayah Brunei, karena sebagian orangtua Brunei beranggapan bahwa pendidikan ala barat tersebut adalah ajaran dari agama kristen yang nantinya akan mempengaruhi agama Islam yang dimiliki masyarakat Brunei dari Suku Melayu.(Suryani, 2014) Selain itu juga, pendidikan agama yang diajarkan di sekolah tidak dimasukkan dalam ujian yang berkisar pada tahun 1930-1964 (Daulay, 2009).

Dengan demikian, pendidikan agama Islam yang tidak masuk dalam kategori ujian, dianggap sebagai ajaran yang telah diajarkan sejak masa anakanak sampai ke jenjang pendidikan selanjutnya sehingga mata pelajaran ini tidak dianggap begitu penting bagi pendidikan pada jenjang formal tetapi sangat ditekankan sistem ajarannya untuk membentuk tingkah laku anak didik di tingkat pendidikan anak-anak masing-masing.

Pendidikan di Brunei masih belum dianggap berhasil pada tahun 1958 sekaligus pada tahun itu juga, Brunei mengambil alih pentabdiran Residen British. Ketidakberhasilan tersebut terlihat dengan jelas bahwa negara Brunei meminta bantuan kepada warga asing untuk memegang jabatan di kerajaan. Sebelumnya, pada saat Sultan Omar Ali Saifuddien III memerintah kerajaan Brunei pada tahun 1950, yang mana kerajaan Brunei yang kaya raya tetapi mengalami kemunduran di berbagai aspek, sehingga pada tahun 1953, raja Brunei memperkenalkan rancangan kemajuan negeri (RKN) di Brunei. Pada tahun sebelumnya juga (1945-1953) telah juga diselenggarakan program perbaikan di Brunei setelelah Brunei dijajah oleh Jepang dan dampak penjajahan tersebut tahun 1941-1945. Akan tetapi usaha raja Brunei yang menjabat waktu itu adalah Sultan Ahmad Tajuddin untuk memperbaiki hal tersebut tidak mendapatkan apresiasi oleh Residen British sehingga ia meminta bantuan kepada London kerajaan Britain mengenai keadaan masa depan Brunei nantinya. Namun, usahanya tidak berkesampaian karena ia telah meninggal terlebih dahulu di Singapura dan digantikan oleh Sultan Omar Ali 
Saifuddien III. Pemerintahan kesultanan yang baru ini meneruskan kembali semangat dan cita-cita raja sebelumnya, baik dalam hal pendidikan, kesehatan, pembekalan air, pembesaran jalan raya, pembinaan jembatan, bangunan infrastruktur jalan, transportasi, komunikasi yang telah disetujui oleh Masjlis Mesyuarat Negeri pada tanggal 29 Juli 1953 (Suryani, 2014). Ketercapaian kemajuan dalam hal pendidikan maupun kemajuan lainnya dilanjutkan kembali oleh sistem pemerintahan seterusnya, yakni Sultan Omar Ali Saifuddien III.

Pengaruh kemerdekaan dari Inggris memberikan nuansa bagi mata pelajaran di Brunei yang mana bahasa Inggris merupakan bahasa yang paling ditekankan. Pada awalnya, pendidikan Inggris belum ada sama sekali di Brunei di tahun 1950. Setelah sekolah yang didirikan oleh Inggris dan diperkenalkan di Brunei pada tahun 1951 baru pendidikan Inggris diperkenalkan. Pendidikan telah diwajibkan dari tingkat TK dengan umur 5 tahun. Setelah pada tingkat TK, maka secara otomatis sudah pada tingkat SD, tetapi untuk ke tingkat selanjutnya hanya kepada siswa tertentu, jika masih belum mampu maka akan tinggal di kelas satu. Tujuan dari pendidikan dasar adalah untuk memberi kemampuan dasar bagi siswa dalam hal menulis, membaca, berhitung (Calistung). Sekolah yang didirikan dari tingkat dasar kemudian didirikan juga tingkat menengah pada tahun 1966. Sekolah tidak hanya didirikan sekolah umum tetapi didirikan juga sekolah Islam yang mempriotiaskan bahasa arab pada tahun 1970 yang tujuannya untuk melanjutkan pendidikan ke Al-Azhar University Kairo tetapi hanya untuk siswa yang memenuhi kriteria. Sementara, untuk mempersiapkan guru-guru agama telah didirikan sekolah guru agama yang didirikan pada tahun 1972. Antusias pendidikan bagi rakyat Brunei sejak tahun 1962-1967. Semenjak Brunei dijajah oleh Inggris dengan memberikan corak kurikulum pendidikan yang berbeda dengan kurikulum pendidikan Brunei sebelumnya sehingga antusias masyarakat Brunei untuk menyekolahkan anaknya tidak seantusias kaum Inggris mendirikan sekolahsekolah Brunei.

Pada tahun 1984, kurikulum pendidikan di Brunei mengalami perubahan dengan mewajibkan bagi peserta didik untuk menguasai bahasa Melayu dan Inggris dan melanjutkan pendidikan ke Perguruan Tinggi di Universiti Brunei Darussalam yang didirikan pada tahun 1985. Sistem pendidikan yang ditetapkan oleh pemerintah untuk rakyat Brunei terdiri dari tiga bagian, yakni sistem dwi bahasa di semua sekolah, konsep Melayu Beraja (MIB) dan pendidikan kejuruan. Bahasa Melayu digunakan untuk mengajar mata pelajaran bahasa Melayu, agama Islam, pendidikan jasmani, lukisan dan pertukangan tangan, sementara bahasa Inggris digunakan untuk mengajar 
mata pelajaran seperti sains, matematika, geografi, sejarah dan bahasa inggris tersebut. Pendidikan lebih ditekankan kepada keahlian teknikal, kejuruan, perdagangan, pertukangan kayu dan mekanik. Masa pendidikan di Brunei pada tingkat dasar selama 7 tahun, tingkat menengah pertama selama 3 tahun, tingkat atas selama 2 dan 2 tahun pra universitas. Lamanya masa studi dikenal dengan pola A7-3-2-2. Kerajaan Brunei juga telah menggalakkan pendidikan, dengan menyediakan asrama dan pengangkutan bagi siswa secara gratis tanpa dipungut biaya sedikit pun. Antusias raja Brunei untuk memberikan pendidikan kepada rakyatnya sangat antusias sekali, yang mana pendidikan diberikan secara gratis tanpa pandang bulu, baik mempunyai intelektual yang tinggi maupun rendah mempunyai layanan yang sama dalam hal pendidikan.

Pendidikan di Brunei lebih banyak mengalami persamaan seperti Indonesia, Malaysia, Singapura, tetapi juga memiliki perbedaan pada tingkat menengah atas yang lebih menekankan pada bahasa Inggris.(Abduh, 2016, hlm. 2-3) Kemudian perbedaan lainnya adalah siswa yang lulus pada tingkat SLTP, maka akan memiliki beberapa pilihan, diantaranya; Pertama, meneruskan ke jenjang SLTA. Di tahun ke dua, setiap siswa akan menjalani ujian penentuan tingkat yang dikenal dengan BCGCE (Brunei Cambridge General Certificate of Education) yang mempunyai dua tingkatan yakni AO dan AN. Siswa yang berprestasi baik maka akan mendapatkan ijazah AO sekaligus dapat meneruskan pra-universitas selama dua tahun dan akan mendapatkan ijazah Brunei Cambridge Advanced Level Certificate tingkat AA, sementara siswa yang tidak berhasil, maka akan mendapatkan ijazah AN dan terpaksa melanjutkan setahun lagi untuk mendapatkan ijazah AO. Kedua, melanjutkan ke sekolah kejuruan seperti perawat kesehatan, kejuruan teknik dan seni, kursus yang bisa langsung ke dunia kerja (Abduh, 2016).

Dengan demikian, layanan khusus untuk intelektual yang khusus maka diberikan semacam ujian untuk melanjutkan kejenjang yang tinggi tanpa menyelesaikan sekolah pada waktu yang telah ditentukan, tetapi diberi keringanan berupa program khusus, sementara yang tidak memenuhi standar yang ditentukan oleh raja Brunei maka akan melanjutkan kembali sesuai dengan waktu jenjang sekolah yang telah ditentukan sebelumnya.

\section{KESIMPULAN}

Kurikulum pendidikan agama Islam yang ada di Brunei mengalami perubahan dengan corak yang berbeda-beda dari perjalanan sejarah negara Brunei yang bersangkutan, baik ketika agama Islam datang, masa penjajahan dan masa kemerdekaan. Dari hasil penelitian yang diperoleh, maka sejarah 
pendidikan agama Islam di Brunei mencakup dari; Pertama, setelah agama Islam datang ke Brunei maka pendidikannya pun tidak terlepas dari materi agama Islam dengan metode untuk mencetak para ulama selanjutnya sebagai pengganti ulama sebelumnya. Kedua, setelah kedatangan kaum penjajah maka pendidikan agama Islam yang diajarkan mengalami dualisme antara kurikulum agama dan kurikulum Inggris, tetapi kurikulum Inggris kurang mendapat sambutan hangat dari sebagian masyarakat Brunei sehingga dilakukan dengan berbagai macam metode seperti mengenalkan sekolah di masjid, tempat-tempat lainnya kemudian dengan sistem denda bagi masyarakat yang tidak menyekolahkan anaknya. Ketiga, setelah negara Brunei merdeka dari jajahan Inggris tetapi kemerdekaan tersebut tidak terlepas juga dari peran Inggris, maka pendidikan yang ada di Brunei tidak terlepas dari pengaruh kurikulum pendidikan dari bangsa Inggris. 


\section{DAFTAR PUSTAKA}

Abduh, H. (2016). Perbandingan Pendidikan Di Negara Brunei Darussalam Dan Negara Kesatuan Republik Indonesia. Hikmah: Jurnal Pendidikan Islam, Vol 5, Iss 1, Pp 01-22 (2016), (1), 1-22.

Aslan. (2018a). Kajian Kurikulum Fiqih Pada Madrasah Aliyah Di Kabupaten Sambas Kalimantan Barat Pada Masyarakat Perbatasan. Madinah: Jurnal Studi Islam, 5(2), 115-124.

Aslan. (2019b). Sejarah Perjalanan Kurikulum Pendidikan Islam di Malaysia. Ta'limuna, 8(1), 29-45.

Bani, S. (2008). Perkembangan Pendidikan Islam Di Brunei Darussalam. Lentera Pendidikan, 11(2), 270-283.

Cahyani, A. I. (2015). Hukum Keluarga Islam di Brunei Darussalam. Jurnal AlQadau, 2(2), 147-160.

Chomsky, N. (t.t.). (2014). Sejarah Brunei Darussalam. Diambil dari https://www.academia.edu/782555/Sejarah_Brunei_Darussalam

Creswell, J. W. (1994). Research Design: Qualitative and Quantitative Approaches. California: Sage Publications, Inc.

Daulay, H. P. (2009). Dinamika pendidikan Islam di Asia Tenggara. Jakarta: Rineka Cipta.

Fitrianah, R. D. (2018). Sistem Pendidikan Islam Berwawasan Multikultural di Negara Asean (Malaysia, Filipina, Singapura dan Brunei Darussalam. AtTa'lim, 17(2), 231-240.

Ghofur, A. (2015). Islam dan Politik di Brunei Darussalam (Suatu TinjauanHistoris). Toleransi: Media Komunikasi Umat Beragama, 7(1), 53-69.

Klasik, U. (t.t.). Melayu Islam Beraja di Negara Brunei Darussalam. Diambil dari https://www.academia.edu/11289857/Melayu_Islam_Beraja_di_Negar a_Brunei_Darussalam

Lubis, M. A., \& Aspar, R. (2005). Kaedah pengajaran pengetahuan agama Islam di Brunei Darussalam. Jurnal Pendidikan, 30, 141-150.

Musa, H. H. (2005). Peranan tulisan Jawi dalam perkembangan Islam di Malaysia. Jurnal Pengajian Melayu. Kuala Lumpur: Universiti Malaya, jilid, 16.

Najtama, F. (2018). Perkembangan Islam di Brunei. Tasamuh, 10(2), 407-421.

Natalia, M. (2015, Juni 11). Warta Sejarah: Pendidikan Islam Di Brunei Darusslam. Diambil 1 Februari 2019, dari WARTA SEJARAH website: 
http:/ / wartasejarah.blogspot.com/2015/06/pendidikan-islam-dibrunei-darusslam.html

Nurudin, M. (2012, Mei 2). PENDIDIKAN ISLAM DI BRUNEI DARUSSALAM. Diambil 31 Januari 2019, dari PENDIDIKAN ISLAM DI BRUNEI DARUSSALAM | Ilmugratis website: http:/ / adinnurudin.blogspot.com/2012/05/pendidikan-islam-dibrunei-darussalam.html

Perkembangan Pendidikan di Brunei 1954-1984. (2011, Januari 3). Diambil 1 Februari 2019, dari Gerbang ilmu website: https:/ /ibnuziad.wordpress.com/2011/01/03/perkembanganpendidikan-di-brunei-1954-1984/

Putra Daulay, H., \& Pasa, N. (2016). Pendidikan Islam Dalam Lintasan Sejarah (Cetakan Ke-3). Jakarta: Kencana.

Rahman, M. bin P. H. A. (2007). Islam di Brunei Darussalam zaman British, 17741984. Dewan Bahasa dan Pustaka Brunei, Kementerian Kebudayaan Belia dan Sukan.

Suryani, N. (t.t.). (2014). Pendidikan di Brunei dari tahun 1953 hingga 1959. Diambil dari https:/ / www.academia.edu/36644063/

Utomo, B. B. (2011). Atlas Sejaran Indonesia Masa Islam, Dirjen Sejarah dan Purbakala, 2011: Atlas Sejaran Indonesia Masa Islam. Indonesia: Bukupedia. 